\title{
IMAGINED SONS 18: GREEK SALAD
}

For a week I travel on business, and on the fourth afternoon, I go to a restaurant to have yet another meal alone. I order a Greek salad and read a Dickens novel to escape my loneliness.

When the salad arrives, I barely look. How will Jenny Wren respond to news of her drunken father's death? I push the fork into the lettuce, and it yields to the tines slowly, satisfyingly. The balance of balsamic vinegar and olive oil, with the sweetness of the red lettuce, is perfect, and I pause, relishing the flavor.

I hear the smallest of shrieks. I think I must have anticipated Jenny, that I must have been that engrossed, when I hear it again, certainly outside me. I put my book down so its open pages press the plastic tablecloth and keep my place, and my fork dives again, spearing a cube of feta.

"Stop! Stop!" The sound rises from the salad.

"Who-what are you?" I whisper. "Where are you?"

A black olive wiggles atop a cos leaf, as though to wave. "I am your son, your only son, brutally transformed!"

I glance around the restaurant and see the other diners, all in groups, engaged in conversation. "When I last saw you, you were an infant. How did you get into this state?" I say with some sharpness.

I think I see him cringe. More meekly, he says, "I fell in love with the virgin mistress of the god's own olive grove; when I made love to her, I was turned into an olive tree!"

"When you made love to her?"

The softest of whispers: "They say, when I raped her."

"So you are a tree as well as this olive?" I ask, trying to move my mouth as little as possible as I see the waiter coming from the kitchen. "So she tends to you, there in the grove?"

"She only knows I disappeared," the olive whines. "She tends to me, yes, but without thought, without love. It is a fate worse than-"

"Delicious," I say to the waiter, swallowing the small olive whole. "Just delicious."

\section{The Iowa Review}

